\title{
PSYCHOGRAPHIC PROFILING OF PROFESSIONAL WOMEN: DEVELOPMENT AND FACTOR ANALYSIS OF ITEMS FOR A QUESTIONNAIRE
}

\author{
*R K Gopal **Seema Sambargi ***Asha Ganesh
}

\section{'ABSTRACT}

Purpose: As a part of a larger study to profile women online shoppers of FMCG/grocery in Bangalore city it was found that there were no instruments available to profile professional women psychographically. The purpose of this study is to develop a set of items for a self-administered questionnaire to profile professional women along psychographic attributes.

Research design and methods: Attributes of personality, values, attitudes, interests, and lifestyles were derived from a focus group discussion with group of eight professional women to arrive at a 28 item questionnaire. Each item was analysed on a five-point Likert scale so as that higher item scores indicated a higher disposition towards that particular attribute. Responses were solicited online through email and also by administering questionnaires to randomly selected professional women. A total of 151(68 online and 83 offline) were evaluated and subjected to an exploratory factor analysis. Meaningful factors were retained and interpreted based on their psychometric properties.

Results: Exploratory factor analysis suggested a five factor solution accounting for $59.9 \%$ of the cumulative variance and all the sub scales had 'acceptable 'reliability (Cronbach alpha greater than 0.6)

Practical Implications: The study has practical implications for grocery/FMCG online retailers for better understanding the shopper behavior in the context of changing consumer psychographic characteristics in an emerging Indian online grocery/FMCG market. The findings may help the online retailers to segment and target the grocery /FMCG consumers and as a consequence, to undertake more effective online retail marketing and advertising strategies for competitive advantage.

Originality/value - Given the absence of published academic literature and empirical findings relating to psychographic profiling of women professions, this study may serve as a departure point for future studies in this area of concern. The research is also relevant to online marketers in terms of format development and reorientation of marketing strategies in the fast growing consumer segment Indian online grocery/FMCG market.

\section{Key Words}

Scale development, factor analysis, psychographic profiling, reliability, online consumer, women professional

\begin{tabular}{|l|l|l|l}
$*$ & $\begin{array}{l}\text { *Dr. R K Gopal } \\
\text { Professor and Director, } \\
\text { CMR Institute of Technology } \\
\text { Bangalore }\end{array}$ & $\begin{array}{l}\text { **Mrs. Seema Sambargi } \\
\text { Associate Professor } \\
\text { Adarsh Institute of Management } \\
\text { and Infonnation Technology } \\
\text { Chamarajpet, Bangalore }\end{array}$ \\
\hline
\end{tabular}




\section{INTRODUCTION AND BACKGROUND}

While internet is being increasingly accepted worldwide for retailing, the challenges for retailers in India are unique with low internet penetration and issues of security and trust. Even so, the Indian online retail market has been growing at a rapid pace in the last 5 years, from around Rs 15 billion revenues, in 2007-08 to Rs 139 billion in 2012-13, translating into a compounded annual growth rate (CAGR) of over 56 per cent According to a CRIS IL report. This is almost 10 -fold growth, according to the same report, came on the back of increasing internet penetration and changing lifestyles and was primarily driven by books, electronics and apparel. CRISIL Research expects the buoyant trend to sustain in the medium term and estimates the market will grow at a healthy $50-55$ per cent CAGR to Rs 504 billion by 2015-16. The drivers of this growth would be the entry of new players in niche and specific segments such as grocery, jewellery and furniture, along with large investments by existing players in the apparel and electronics verticals. There is tremendous potential since in terms of size, India's online retail industry is very small compared with both organised and overall (organised plus unorganised) retail in the country.

The retail industry has been characterized by a shift from the unorganized to an organized one, which included a shift from the kirana store format to the formats like department stores, hypermarkets, supermarkets and specialty stores across the different range of product categories. As the competition is increasing, retailers are seeking different ways to engage and retail the customers. The use of Internet is catching up as alternative channel for retailing in India and it is now an acknowledged and important part of the retail experience. The momentum and growth of the Indian retail industry coupled with the development of the requisite infrastructure and increasing awareness of online shopping would give a further boost to the online shopping industry.

In this back drop, as a part of a larger study to profile women online shoppers of FMCG/grocery in Bangalore city, a gap was noticed. While it was fairly easy and straight forward to come up with items to profile women online grocery/FMCG shoppers along demographic variables( age, income, marital status and such),geographic variables, shopping behavior etc., items to measure psychographic variable like lifestyle and values were absent in the literature survey conducted by the researcher.

\section{REVIEW OF LITERATURE}

That the consumers socio-economic environment, personality and his past purchase experience have an influence on the store and the format choice has been indicated by many studies (Dodge and Summer, 1969; Bearden et al., 1978;Aaker and Morgan Jones, 1971; Pessemier, 1980; Shim and Kotsiopulos, 1992; Leszczyc et al., 2000 Baltas and Papastathopoulou, 2003). Also, while some studiers have established a relationship between consumer behavior and values (Kahle, 1986 ; Sheth et al., 1991; Erdem et al., 1999), others have identified significant associations between attitude and purchase intentions with respect specialty items (Summers et al., 2006; Belleau et al., 2007). In the western markets, traditional demographics have failed to provide a complete picture of the customers, as the same demographic group may possess different psychographic characteristics (Lilien and Kotler, 1983.) In the Indian online context, there were no significant associations between shopping segments and demographic values (Darshan Parikh, 2008). Accurate prediction of consumer behaviour for commercial gains (Hoek et al., 
1996) and proper market segmentation (Cooper, 1984) are achieved if psychographic information is available about the consumers.

The developed nations attempts to segment consumers on the basis of psychographic variables in various studies (Stone, 1954; Baker and Fletcher, 1987: ). Many instruments have evolved over a period of time to measure psychographic variables. They include the Activities, Interests and Opinions (AIO) battery of questions (Wells and Tigert. 1971), the Rokeach Value Survey (RVS; Rokeach, 1973), the List of Values (LOV) (Kahle, 1983) and Value and Lifestyle Segmentation (VALSTM) developed by SRIC Business Intelligence (1978).

In the Indian context, a study to segment youth psychographically (Narang, 2011) was successful but there are hardly any instruments available to psychographically segment women consumers and almost none to psychographically profile professional women. While it was fairly easy and straight forward to come up with items to profile women online grocery/FMCG shoppers along demographic variables (age, income, marital status and such) geographic variables, shopping behaviour etc., items to measure psychographic variable of women like lifestyle and values were absent in the literature survey conducted by the researcher.

\section{OBJECTIVE}

In light of the above literature review, the purpose of this study is to develop a set of items for a self-administered questionnaire to profile professional women along psychographic attributes.

\section{RESEARCH METHODOLOGY}

\section{Generating a battery of items to measure lifestyle and values.}

A focus group discussion of eight women professionals from various industries was arranged. Care was taken to ensure that these eight people came from different industries with due representation from varied socio economic backgrounds and age groups. The composition of the focus group was thus-a 26 year old school teacher, 32 year old lawyer. 43 year old doctor, 48 year old college professor, 52 year old banker, retired government servant, 40 year old entrepreneur and a 38 year old IT professional. Six of them were married, one did not have children and one had a empty nest. The group was briefed and asked to come up with statements that best described the personalities, concerns and values of themselves, colleagues and friends who were professional women. The group came up with many life style and value concerns of women professions. Following is the initial list of 28 statements that would purportedly measure the life style and values dimension of the psychographic variable.

1. Need others to recognize my achievements

2. Career gives me purpose in life

3. First obligation is to home and family

4. It is more important to spend money on family than to spend it on myself

5. Follow traditions handed down by family

6. Have to be financially independent

7. Having people to do what I say is very important

8. Work too many hours at office

9. It is important to be rich and wealthy

10. Devote myself to those around me

11. Feel torn between family and work 
12. Understand the purpose of one's life

13. Have a belief system that helps me make a sense of of my life

14. Overwhelmed by all the decisions that have to be made

15. Doing new things is extremely important

16. The household work is too much to manage

17. Feel relaxed most of the time

18. Feel stressed and rushed most of the times

19. It is very important that people admire my abilities

20. Love to take risks

21. A very high energy person

22. Lead a very active social life

23. Very health conscious

24. It is very important to seek out things that give personal pleasure

25. Feel that I am always struggling and managing one crisis after another

26. Spoil myself by indulging.

27. I am a fitness freak

28. Doing household chores is a waste of time

This list of 28 statements were presented to a panel of three academicians and tested for content validity and wordings. The statements 'I am a fitness Freak' and 'Doing household chores is a waste of time' were deemed ambiguous and unfit by the panel. The remaining 26 items were retained in a questionnaire with each item being measured on a five-point Likert scale so as that higher item scores indicated a higher disposition towards that particular attribute.

\section{Sampling and questionnaire administration.}

Responses were solicited online through email by making use of Google Forms using convenience sampling and also by administering questionnaires to randomly selected 100 professional women. A 'professional woman' was operationally defined as woman who has undergone prolonged training or a formal qualification for an occupation. A total of 151 (68 online and 83 offline) were fit for the pilot study evaluation. While the rate of response in offline survey was a high $83 \%$, the rate of response using online survey cannot be accurately calculated since snowball and convenient sampling method was used.

\section{ANALYSISAND RESULTS}

A principal component analysis (PCA) was conducted on the 26 items with orthogonal rotation (varimax). The Kaiser-Meyer-Olkin measure verified the sampling adequacy for the analysis, $\mathrm{KMO}=0.7$ ('superb' according to Field, 2009), and all KMO values for individual items were $>0.5$, which is well above the acceptable limit of .5 (Field, 2009). Bartlett's test of sphericity, $\chi 2(136)=608.671, \mathrm{p}<.001$, indicated that correlations between items were sufficiently large for PCA. An initial analysis was run to obtain eigenvalues for each component in the data. A few statements had ambiguous rotation factor loadings. After deleting such items, five components had eigenvalues over Kaiser's criterion of 1 and in combination explained $59.91 \%$ of the variance. Since the scree plot also justified retainment of five components, this is the number of components that were retained in the final analysis. Table 1.1 shows the factor loadings after rotation. These five factors were named 
(Table 1.2) and reliability analysis conducted.

The five factors and the items in each factor are tabulated as under.

\begin{tabular}{|c|c|c|c|c|c|}
\hline \multirow[b]{2}{*}{ Item } & \multicolumn{5}{|c|}{ Rotated Component Matrix } \\
\hline & Struggler & Go- & $\begin{array}{l}\text { Self- } \\
\text { assured }\end{array}$ & $\begin{array}{l}\text { Social } \\
\text { climber }\end{array}$ & $\begin{array}{l}\text { Family } \\
\text { oriented }\end{array}$ \\
\hline $\begin{array}{l}\text { 1. Feel that } I \text { am always struggling } \\
\text { and managing one crisis after another }\end{array}$ & $.774^{6}$ & & & & \\
\hline $\begin{array}{l}\text { - Feel stressed and rushed most of } \\
\text { the times }\end{array}$ & .689 & & & .114 & .113 \\
\hline - Spoil myself by indulging & .590 & & & & -.363 \\
\hline - Feel torn between family and work & .586 & -.125 & .309 & & \\
\hline $\begin{array}{l}\text { - It is very important that people } \\
\text { admire my abilities }\end{array}$ & .462 & .414 & & .373 & .154 \\
\hline - A very high energy person & & .773 & .176 & .144 & .103 \\
\hline - love to take risks & & .744 & & .220 & -.137 \\
\hline - Career gives me purpose in life & .138 & .574 & .183 & .307 & .343 \\
\hline $\begin{array}{l}\text { - Have a belief system that helps } \\
\text { me make a sense of of my life }\end{array}$ & -.110 & .124 & .853 & .102 & \\
\hline - Understand the purpose of one's life & & .275 & .779 & & .150 \\
\hline - Devote myself to those around me & .146 & -.151 & .696 & .142 & .165 \\
\hline $\begin{array}{l}\text { - Need others to recognise my } \\
\text { achievements }\end{array}$ & .213 & .191 & & .697 & \\
\hline - Lead a very active social life & & .377 & & .662 & .158 \\
\hline - Doing new things is extremely important & & .246 & .192 & .649 & \\
\hline $\begin{array}{l}\text { Having people to do what I say } \\
\text { is very important }\end{array}$ & .247 & -.433 & .106 & .596 & \\
\hline $\begin{array}{l}\text { It is more important to spend money } \\
\text { on family than to spend it on myself }\end{array}$ & & & .147 & & .822 \\
\hline - Follow traditions handed down by family & & & .169 & & .808 \\
\hline
\end{tabular}

Table 1.2

\begin{tabular}{|c|c|c|}
\hline Factor No. & Name of the sub scale & Items \\
\hline 1 & Struggler & $\begin{array}{l}\text { 1. Feel that I am always struggling and managing one crisis after another } \\
\text { 2. Feel stressed and rushed most of the times } \\
\text { 3. Spoil myself by indulging } \\
\text { 4. Feel tom between family and work }\end{array}$ \\
\hline 2 & Go-getter & $\begin{array}{l}\text { 1. A very high energy person } \\
\text { 2. Love to take risks } \\
\text { 3. Career gives me purpose in life }\end{array}$ \\
\hline 3 & Self-assured & $\begin{array}{l}\text { 1. Have a belief system that helps me make a sense of my life } \\
\text { 2. Understand the purpose of one's life } \\
\text { 3. Devote myself to those around me }\end{array}$ \\
\hline 4 & Social Climber & $\begin{array}{l}\text { 1. Need others to recognise my achievements } \\
\text { 2. Lead a very active social life } \\
\text { 3. Doing new things is extremely important } \\
\text { 4. Having people to do what I say is very important }\end{array}$ \\
\hline 5 & Family oriented & $\begin{array}{l}\text { 1. It is more important to spend money on family than to spend it on mysel } \\
\text { 2. Follow traditions handed down by family }\end{array}$ \\
\hline
\end{tabular}

\section{Reliability Analysis of the sub scales}

All sub scales, 'Struggler',' Go-getter', ‘Self -assured', 'Social climber' and 'Family-Oriented' of the psychographic questionnaire have acceptable Cronbach's alpha greater than 0.6 


\section{Discussion and Managerial Implications}

The study has practical implications for grocery/FMCG online retailers for better understanding the shopper behaviour in the context of changing consumer psychographic characteristics in an emerging Indian online grocery/FMCG market. Also with the increase in number of women professionals, the ability to segment and target this increasingly influential and affluent class is extremely important for marketers in general. The findings may help the online retailers to segment and target the grocery /FMCG consumers and, as a consequence, to undertake more effective online retail marketing and advertising strategies for competitive advantage

\section{COMNCLUSION}

The study has successfully achieved the objectives of segmenting the Indian professional women on the basis of psychographics and has made significant contribution to both the online retail industry and academia. It throws light on the lifestyle of prefessional women in a cosmopolitan city thus equipping the online retailer with adequate and valuable information to design tools to attract the professional women consumers. As mentioned earlier, the findings may help the online retailers to segment and target the grocery /FMCG consumers and hence develop and undertake more effective online retail marketing and advertising strategies for competitive advantage. Moreover, it extends the current literature and provides a basis for further research. However, as the study was confined to the city of Bangalore, any generalisation to the Indian nation has to be made cautiously. Moreover, the use of convenience sampling to solicit online responses has its limitations as it ignores allege part of the population. Further research may be carried out to understand the behaviour of the factors extracted in a much larger sample.

\section{References}

- Aaker, D. A., \& Jones, J. M. (1971). Modelling store choice behaviour. Journal of Marketing Research, 38-42.

- Baker, K. and Fletcher, R. (1987), "Outlook-a generalized lifestyle system", Admap, March, pp. 23-8.

- Baltas, G., \& Papastathopoulou, P. (2003). Shopper characteristics, product and store choice criteria: a survey in the Greek grocery sector. International Journal of Retail
\& Distribution Management, 31(10), 498-507.

- Bearden, W. O., Teel, J. E., \& Durand, R. M. (1978). Media usage, psychographic, and demographic dimensions of retail shoppers. Journal of Retailing, 54(1), 65-74.

- Belleau, B. D., Summers, T. A., Xu, Y., \&Pinel, R. (2007). Theory of Reasoned Action Purchase Intention of Young Consumers. Clothing and Textiles Research Journal, 25(3), 244-257.

- Cooper, P. D. (1984). Elderly segmentation: a factor analytic approach to psychographic segmentation. In Proceedings of the Annual Meeting of the Southern Marketing Association (pp. 28-31). Florida Atlantic University.

- Dodge, H. R., \& Summer, H. H. (1969). Choosing between retail stores. Journal of retailing, 45(3), 11-21.

- Erdem, O., Oumlil, A. B., \& Tuncalp, S. (1999). Consumer values and the importance of store attributes. International Journal of Retail \& Distribution Management, 27(4), 137 144.

- Field, A. (2009). Discovering statistics using SPSS. Sage publications.

- Hoek, J., Gendall, P., \& Esslemont, D. (1996). Market segmentation: a search for the Holy Grail?. Journal of Marketing Practice: Applied Marketing Science, 2(1), $25-$ 34.

- Kahle, L. R. (1986). The nine nations of North America and the value basis of geographic segmentation. The Journal of Marketing, 37-47.

- Kahle, L. R., Beatty, S. E., \& Homer, P. (1986). Alternative measurement approaches to consumer values: the list of values (LOV) and values and life style (VALS). Journal of consumer research, 405-409.

- Lilien, G. L., \& Kotler, P. (1983). Marketing decision making: A model-building approach. New York: Harper \& Row.

- Narang, R. (2011). Examining the role of various psychographic characteristics in apparel store selection: $a$ study on Indian youth. Young Consumers: Insight and Ideas for Responsible Marketers, 12(2), 133-144.

- Parikh, D. (2006). Profiling Internet Shoppers: A Study of Expected Adoption of Online Shopping in India. IIMB Management Review, 18(3), 221-231.

- Pessemier, E. A. (1980). Store image and positioning. Journal of Retailing, 56(1), 94-106.

- Popkowski Leszczyc, P. T., Sinha, A., \& Sahgal, A. (2004).The effect of multi-purpose shopping on pricing and location strategy for grocery stores. Journal of Retailing, 80(2), 85-99.

- Rokeach, M. (1973). The nature of human values (Vol. 438). New York: Free press.

- Sheth, J. N., Newman, B. I., \& Gross, B. L. (1991). Why we buy what we buy: a theory of consumption values. Journal of business research, 22(2), 159-170.

- Summers, T. A., Belleau, B. D., \& Xu, Y. (2006). Predicting purchase intention of a controversial luxury apparel product. Journal of Fashion Marketing and Management, 10(4), 405-419.

- Wells, W. D., Tigert, D. J. (1971)., Activities, Interests and Opinions. Journal of advertising research, 11(4), 27-35. 